\title{
Leiomyoma in the space of Retzius: a rare location
}

\author{
Shweta $^{1 *}$, Shaheen Anjum ${ }^{1}$, Zehra Mohsin ${ }^{1}$, Afzal Anees ${ }^{2}$
}

\begin{abstract}
${ }^{1}$ Department of Obstetrics and Gynecology, Jawaharlal Nehru Medical College and Hospital, Aligarh Muslim University, Aligarh, Uttar Pradesh, India

${ }^{2}$ Department of Surgery, Jawaharlal Nehru Medical College and Hospital, Aligarh Muslim Universit, Aligarh, Uttar Pradesh, India
\end{abstract}

Received: 08 April 2020

Accepted: 30 April 2020

\author{
*Correspondence: \\ Dr. Shweta, \\ E-mail: shwetatanur@gmail.com
}

Copyright: (C) the author(s), publisher and licensee Medip Academy. This is an open-access article distributed under the terms of the Creative Commons Attribution Non-Commercial License, which permits unrestricted non-commercial use, distribution, and reproduction in any medium, provided the original work is properly cited.

\begin{abstract}
Extrauterine locations of leiomyomas are extremely rare clinical conditions as in the case of space of Retzius. Space of Retzius is a small anatomical compartment located posterior to the pubic symphysis and anterior to the urinary bladder. Here authors report a very unique case of 22-year-old woman presented to the study hospital with complaints of inability to conceive and difficulty in urination. Clinical examination and imaging of pelvis suggest leiomyoma of uterus located between lower part of anterior uterine wall and bladder. An attempt to remove the tumour laparoscopically was taken but later it was converted into open laparotomy due to unusual location of leiomyoma. Histopathology revealed the tumour to be a leiomyoma.
\end{abstract}

Keywords: Extrauterine, Leiomyoma, Retropubic space, Space of Retzius

\section{INTRODUCTION}

Leiomyomas are the most common gynaecological tumour affecting the women of reproductive age group. Extra uterine fibroids are not as common as uterine fibroids. Histologically, these tumours are benign and originate from smooth muscle cells. Rare location of these tumours is bladder, urethra, vulva, ovaries, fallopian tube, broad ligament, space of Retzius. Space of Retzius is an extraperitoneal space anterior to urinary bladder and posterior to pubic symphysis. This space is a surgical landmark in various gynaecological and urological surgeries like sling surgery in women with stress incontinence, artificial urinary sphincter, burch colpo-suspension. ${ }^{1}$ Majority of cases in the space of Retzius are leiomyomas, the rest involves neoplastic conditions like cystic lymphangioma, an angiomyxoma and a spindle cell lipoma and non-neoplastic conditions like abscesses and hematomas. ${ }^{2-6}$ Leiomyomas in the space of Retzius usually remain silent and later present with pelvic pain, pelvic mass and bladder voiding difficulties when size increases. ${ }^{7}$

\section{CASE REPORT}

A 22 years old female visited study hospital with chief complaints of inability to conceive for 2 years and bladder voiding symptoms characterized by feeling of incomplete voiding and pelvic pain. There was no menstrual complain. General and systemic examinations were normal. On pelvic examination, a mass was felt of about $7 \mathrm{~cm}$ in the anterior cervix which was immobile and fixed. Also, there was fullness in postero-right fornix due to which cervix was displaced to the left side. Patient had come with trans-abdominal ultrasound and CT scan pelvis. Ultrasound showed a $59 \mathrm{~mm}$ subserosal fibroid in the anterior cervical region with simple cyst of 86-50 mm without any septa or solid component in the right adnexa. CT-pelvis suggested a large well-defined multi-lobulated solid enhancing lesion anterior to vagina and inferior to urinary bladder with the possibility of round cell tumour measuring $7 \mathrm{~cm}$ antero-posteriorly, $5.8 \mathrm{~cm}$ transversely and $6 \mathrm{~cm}$ crania-caudally; also, the lesion was seen to be causing indentation in the inferior wall of the uterus. Also, well defined non-enhancing hypo-dense cystic 
lesion was seen in right adnexa measuring $8.4 \times 6 \mathrm{~cm}$. Her laboratory test was within normal limits. Husband seminogram was normal.

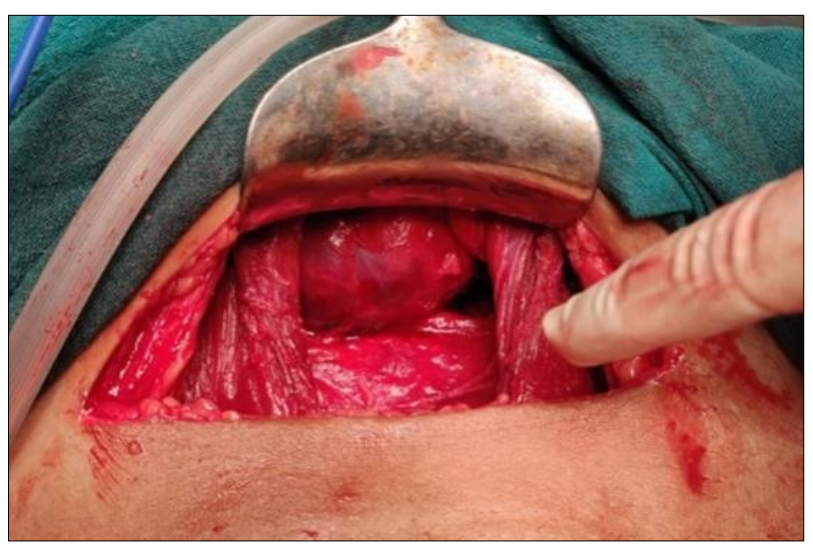

Figure 1: Per op gross leiomyoma in space of Retzius.

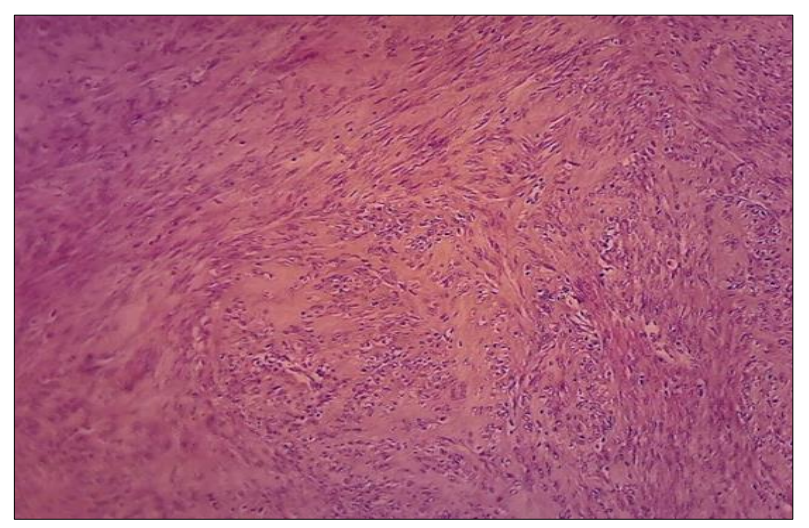

Figure 2: Microscopic view of leiomyoma in LPF.

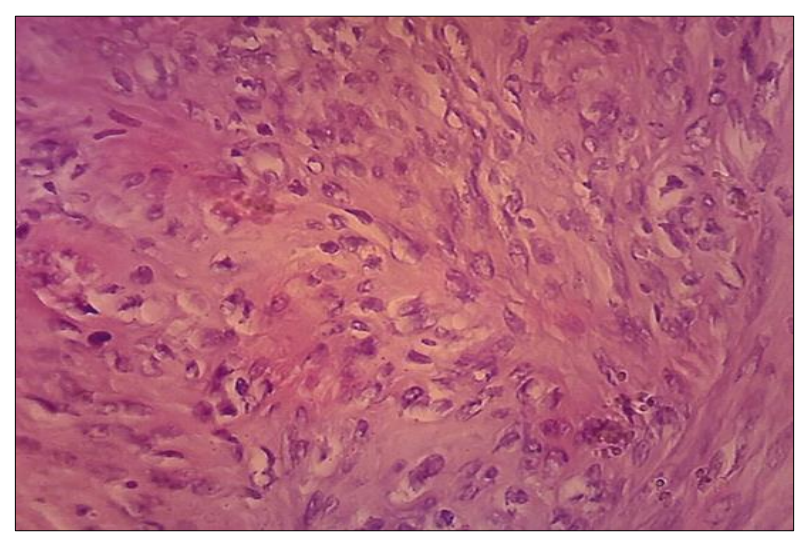

Figure 3: Microscopic view of leiomyoma in HPF.

She was planned for hystero-laparoscopy for laparoscopic myomectomy, ovarian cystectomy along with the tubal patency test. On hysteroscopy, uterine cavity was normal with normal bilateral ostia. On laparoscopy, both the tubes were normal and patent. There was an ovarian cyst of about $8 \times 7 \mathrm{~cm}$ present in right ovary. Cystectomy was done laparoscopically and tissue sent for histopathological examination. As the myoma was not arising from uterus and its location was above the bladder, the decision of converting laparoscopy to laparotomy was taken.

During laparotomy, as shown in Figure 1, a firm almost round mass of about $7 \times 6 \mathrm{~cm}$ was found in the retropubic and prevesical space, and arising from the space of Retzius. Moreover, the mass was not having any attachment to uterus and bladder. The tumour was removed in-toto from the prevesical space. The postoperative course was uneventful and the patient was discharged from the hospital after 7 days of surgery.

Histopathological examination of the specimen revealed the presence of leiomyoma and serous cyst adenoma. The patient was left for spontaneous conception for next 6 months.

\section{DISCUSSION}

Although the uterus is the most common site of origin of leiomyomas, the lesions arise as proliferations of smooth muscle cells, and they may develop at any site where such cells are found. Unusual sites of origin include the vulva, ovaries, urinary bladder, urethra and space of Retzius. Extrauterine lieomyomas are extremely rare. They are a diagnostic challenge due to the unusual locations that they arise from.

Leiomyomas detected in the extraperitoneal space, occur with $73 \%$ frequency in the pelvis minor and $<1 \%$ of leiomyomas are located in the broad ligament of the uterus, which is an extremely rare location. ${ }^{8,9}$

The space of Retzius is the space between the pubic symphysis and the urinary bladder and is a part of extra peritoneal space. It is also named as retropubic or anterovesical, paravesical and pararectal, retropubic space, cave of Retzius, Retzius cavity. This space is located between transversalis fascia of the abdominal wall and the parietal peritoneum. ${ }^{10}$ Its floor is delineated by the pubovesical ligament and Santorini's retropubic venous plexus. In the literature so far, only few cases of leiomyomas in the Retzius space has been reported. ${ }^{11-14}$

Tumours in the space of Retzius are infrequent in females, mostly having benign histology. Aggressive cancers in the space of Retzius mostly arise from adjacent tissue (vulva, urachal remnant). ${ }^{15,16}$ Benign tumours of the space of Retzius mostly arise from connective tissue and have a good prognosis. Differential diagnosis of the mass in the space of Retzius are granuloma, hemangiopericytoma, lymphangioma, neurinoma, subpubic cartilaginous cyst and very rarely leiomyoma. ${ }^{17,18}$

Imaging studies is of utmost importance to precisely locate a new growth in the extra-peritoneal space. On CTscan, mass is usually seen as a homogenous mass. ${ }^{19}$ 
Preoperatively, diagnostic transdermal biopsy and histopathological examination can help to make a diagnosis and find out the type of tumour. ${ }^{11}$ In the case presented here, the preoperative diagnosis was difficult because the ultrasound findings revealed the tumour as subserosal fibroid in the anterior cervical region whereas the CT-scan showed it to be a round cell tumour between the pubic symphysis and urinary bladder and causing indentation in anterior uterine wall. But due to the poor affordability of the patient, further investigations were not done and decision for laparoscopic myomectomy and cystectomy was taken.

Histopathological examination of the myoma as shown in Figure 2 and Figure 3 showed whorled pattern of smooth muscle bundles with cigar like nuclei with eosinophilic fibrillar cytoplasm separated by well vascularised septa. Few cystic changes and hyalinized blood vessels were seen and impression of leiomyoma was given.

\section{CONCLUSION}

Leiomyoma of the Retzius space is a very rare benign tumour. To make correct preoperative diagnosis, imaging diagnostics like MRI, CT-scan should be used which later helps in making best surgical plan. Treatment of tumour in the space of Retzius is surgical only. Complete excision of the tumour should be done and further management should be carried out after getting the histopathological report.

\section{Funding: No funding sources}

Conflict of interest: None declared

Ethical approval: The study was approved by the Institutional Ethics Committee

\section{REFERENCES}

1. Burkhard FC, Bosch JL, Cruz F, Lemack GE, Nambiar AK, Thiruchelvam N, Tubaro A. EAU guidelines on urinary incontinence. Arnhem, The Netherlands. Eur Associat Urol. 2016:88.

2. Kosumi T, Kubota A, Yonekura T, Yamauchi K. Cystic lymphangioma of Retzius space manifested as acute abdomen. Eu J Pediatr Surg. 2006;16(02):120-2.

3. Payne S, Adair R, Alvarez J, Heller D, Caggiano A. Aggressive angiomyxoma of the space of retzius: a case report. J Low Genit Tract Dis. 2003;7:304.

4. Okuda H. Spindle cell lipoma in Retzius' space. Int J Urol. 2009;16:218.

5. Borten M, Friedman EA. Spontaneous prevesical (Retzius-space) abscess with extraperitoneal presacral dissemination. J Reprod Med. 1984;29:841.
6. Dupas B, Barrier J, Michel P, Rymer R, Paineau J, Venisse T, Fiche M, Rodat O, Grolleau JY. Diagnosis of hematomas in the Retzius space during anticoagulant therapy. Prospective study (11 cases). Sem Hop. 1983;59:3115

7. Pepe F, Pepe P, Rapisarda F, Fauzia M, Giunta M. Giant leiomyoma of the retzius space: a case report. Case Rep Obstet Gynecol. 2013;2013:371417.

8. Bakari F, Sulayman HU, Avidime S, Ameh N, Adesiyun AG. Huge broad ligament leiomyoma: a case report. Case Reports in Clinic Med. 2015;4:55-9.

9. Chmaj-Wierzchowska K, Buks J, Wierzchowski M, Szymanowski K, Opala T. Leiomyoma cellulare in the broad ligament of the uterus - case report and review of literature. Ginekol Pol. 2012;83(4):301-4.

10. Shanbhogue AKP, Fasih N, Macdonald DB, Sheikh AM, Menias CO, Prasad SR. Uncommon primary pelvic retroperitoneal masses in adults: a pattern-based imaging approach. Radiograph. 2012;32:795-817.

11. Niwa $N$, Yanaihara $H$, Horinaga $M$, Asakura $H$. Leiomyoma in retzius' space: an unusual location. Can UrolAssoc J. 2013;7: E612-613.

12. Stutterecker D, Umek W, Tunn R, Sulzbacher I, Kainz C. Leiomyoma in the space of Retzius: a report of 2 cases. Am J Obstet Gynecol. 2001;185:248-9.

13. Reisenauer C, Walz-Mattmueller R, Solomayer EF, Siegmann K, Wallwiener D, Wehrmann M. Leiomyoma in the Retzius space: a rare cause for voiding difficulties. Int Urogynecol J Pelvic Floor Dysfunct. 2007;18:1229-31.

14. Molina Granados J, Escribano Fernández J, Alegre Castellanos Á. Leiomioma gigante del espacio de Retzius. Cirugia Espanola 2010; 88: 49-50.

15. Tan $\mathrm{CH}$, Vikram R, Boonsirikamchai P, Faria SC, Charnsangavej C, Bhosale PR. Pathways of extrapelvic spread of pelvic disease: imaging findings. Radiograph. 2011;31(1):117-33

16. Payne S, Adair R, Alvarez J, Heller D, Caggiano A. Aggressive angiomyxoma of the space of retzius: a case report. J Lower Genital Tract Dis. 2003;7(4):304-6.

17. Donnola G, Tagariello P, Tagariello C. A voluminous prevesical hemangiopericytoma. A clinical case report. Minerva Chirurgica. 1997;52(5):673-8.

18. Ghareeb GM, Grabemeyer H, Dietrich E, Heisler CA. Subpubic cartilaginous cyst presenting as acute urinary retention: a report and review of the literature. Female Pelvic Med Reconst Surg. 2013;19(1):58-60.

19. Fasih N, Prasad Shanbhogue AK, Macdonald DB, Fraser-Hill MA, Papadatos D, Kielar AZ, Doherty GP, Walsh C, McInnes M, Atri M. Leiomyomas beyond the uterus: unusual locations, rare manifestations. Radiograph. 2008;28(7):1931-48.

Cite this article as: Shweta, Anjum S, Mohsin Z, Anees A. Leiomyoma in the space of Retzius: a rare location. Int J Reprod Contracept Obstet Gynecol 2020;9:2656-8. 